The University of Maine

DigitalCommons@UMaine

Earth Science Faculty Scholarship

Earth Sciences

1990

\title{
The Dominion Range Ice Core, Queen Maud Mountains, Antarctica - General Site and Core Characteristics with Implications
}

Paul Andrew Mayewski

University of Maine, paul.mayewski@maine.edu

Mark S. Twickler

William Berry Lyons

Mary Jo Spencer

Debra A. Meese

See next page for additional authors

Follow this and additional works at: https://digitalcommons.library.umaine.edu/ers_facpub

Part of the Glaciology Commons, and the Hydrology Commons

\section{Repository Citation}

Mayewski, Paul Andrew; Twickler, Mark S.; Lyons, William Berry; Spencer, Mary Jo; Meese, Debra A.; Gow, Anthony J.; Grootes, Pieter; Sowers, Todd; Watson, M. Scott; and Saltzman, Eric, "The Dominion Range Ice Core, Queen Maud Mountains, Antarctica-General Site and Core Characteristics with Implications" (1990). Earth Science Faculty Scholarship. 264. https://digitalcommons.library.umaine.edu/ers_facpub/264

This Article is brought to you for free and open access by DigitalCommons@UMaine. It has been accepted for inclusion in Earth Science Faculty Scholarship by an authorized administrator of DigitalCommons@UMaine. For more information, please contact um.library.technical.services@maine.edu. 


\section{Authors}

Paul Andrew Mayewski, Mark S. Twickler, William Berry Lyons, Mary Jo Spencer, Debra A. Meese, Anthony J. Gow, Pieter Grootes, Todd Sowers, M. Scott Watson, and Eric Saltzman 


\title{
THE DOMINION RANGE ICE CORE, QUEEN MAUD MOUNTAINS, ANTARCTICA - GENERAL SITE AND CORE CHARACTERISTICS WITH IMPLICATIONS
}

\author{
By paul A. Mayewski, Mark S. Twickler, Wm Berry Lyons, mary Jo Spencer, \\ (Glacier Research Group, Institute for the Study of Earth, Oceans and Space (EOS),
} University of New Hampshire, Durham, New Hampshire 03824, U.S.A.)

Debra A. MEese,

(Glacier Research Group, Institute for the Study of Earth, Oceans and Space (EOS), University of New Hampshire, Durham, New Hampshire 03824, U.S.A., and U.S. Army Cold Regions Research and Engineering Laboratory, Hanover, New Hampshire 03755, U.S.A.)

ANTHONY J. Gow,

(U.S. Army Cold Regions Research and Engineering Laboratory, Hanover, New Hampshire 03755, U.S.A.)

PIETER Grootes,

(Quaternary Isotope Laboratory, University of Washington, Seattle, Washington 98195, U.S.A.)

TODD SOWERS,

(Graduate School of Oceanography, University of Rhode Island, Narragansett, Rhode Island 02882, U.S.A.)

M. ScOtT Watson,

(Polar Ice Coring Office, University of Nebraska, Lincoln, Nebraska 68558, U.S.A.)

and ERic Saltzman

(Rosenstiel School of Marine and Atmospheric Sciences, University of Miami, Miami, Florida 33149, U.S.A.)

ABSTRACT. The Transantarctic Mountains of East Antarctica provide a new milieu for retrieval of ice-core records. We report here on the initial findings from the first of these records, the Dominion Range ice-core record. Sites such as the Dominion Range are valuable for the recovery of records detailing climate change, volcanic activity, and changes in the chemistry of the atmosphere. The unique geographic location of this site and a relatively low accumulation rate combine to provide a relatively long record of change for this potentially sensitive climatic region. As such, information concerning the site and general core characteristics are presented, including ice surface, ice thickness, bore-hole temperature, mean annual net accumulation, crystal size, crystal fabric, oxygen-isotope composition, and examples of ice chemistry and isotopic composition of trapped gases.

\section{INTRODUCTION}

Localized accumulation basins in the Transantarctic Mountains, fed completely by precipitation on to the site, provide a new avenue for Antarctic ice-core research. These sites are valuable for the recovery of records detailing climatic change, volcanic activity, and changes in atmospheric chemistry for periods extending well into the last glacial period. Since these sites are located within the transitional zone between plateau ice and ocean-ice shelf, they could provide some of the most climatically sensitive records available from Antarctica. Furthermore, unlike those ice cores retrieved from the interior of Antarctica, there are terrestrial records from nearby sites that can be used for comparison (e.g. Denton and others, 1971; Drewry, 1980; Stuiver and others, 1981; Mayewski and Goldthwait, 1985).

The Dominion Range (Fig. 1) is the first in a series of planned Transantarctic Mountains ice-core sites (Fig. 1). The Dominion Range is located along the edge of the East Antarctic ice sheet, approximately $500 \mathrm{~km}$ from the South Pole and $120 \mathrm{~km}$ from the Ross Ice Shelf, at the confluence of Beardmore and Mill Glaciers (Fig. 2). These glaciers, along with several other outlet glaciers in the Queen Maud Mountains (sub-sector of the Transantarctic Mountains), drain the Titan Dome area of the East Antarctic ice sheet. Approximately half of the Dominion Range (Fig. 2) is icefree and the average elevation of the range is $2700 \mathrm{~m}$.

Between 20 November and 14 December 1984, a tent camp was operated in the Dominion Range. Due to logistic restraints, all aspects of the study, including reconnaissance, site characterization, and recovery of a $201 \mathrm{~m}$ core were undertaken in the same field season. In this paper we present the results of site and core characterization, specifically ice surface and ice thickness, bore-hole temperature, mean annual net accumulation, crystal size, crystal fabric, oxygen-isotope composition, and examples of ice chemistry $\left(\mathrm{Cl}^{-}, \mathrm{SO}_{4}^{2-}, \mathrm{MSA}\right)$, and isotopic composition of trapped gases. 


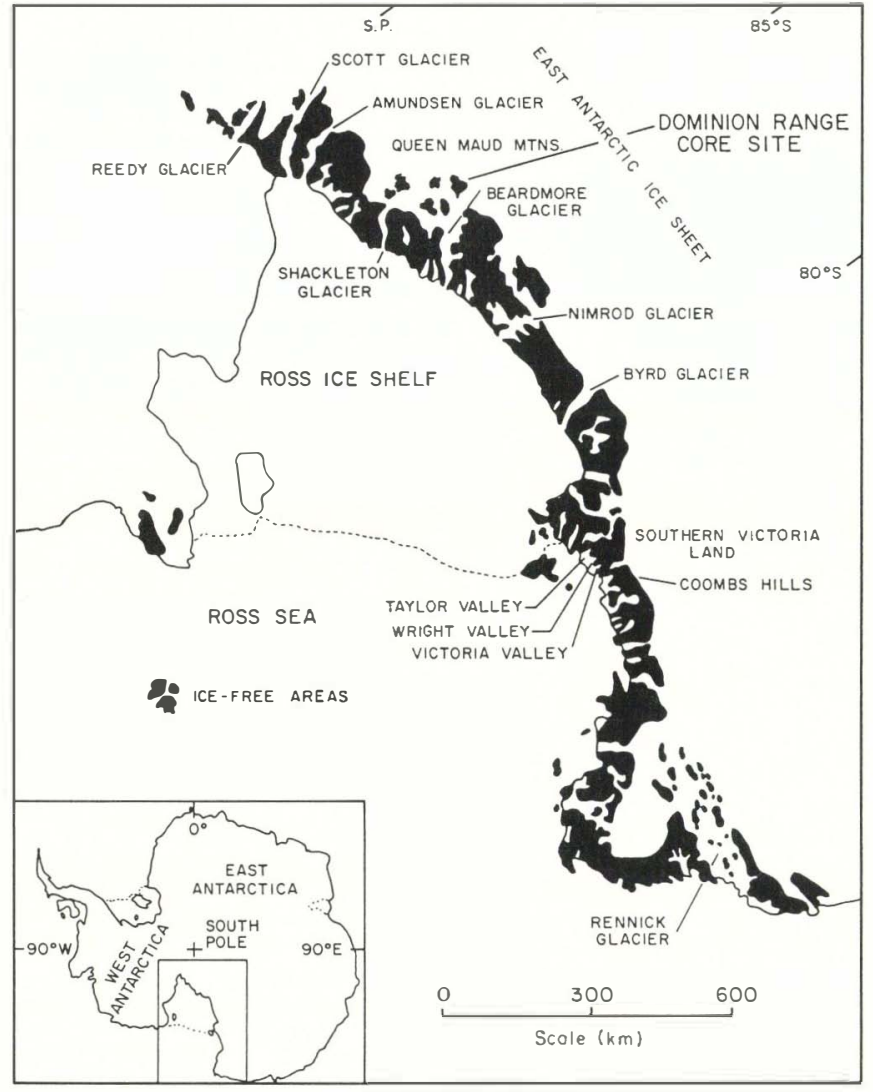

Fig. 1. Location map.

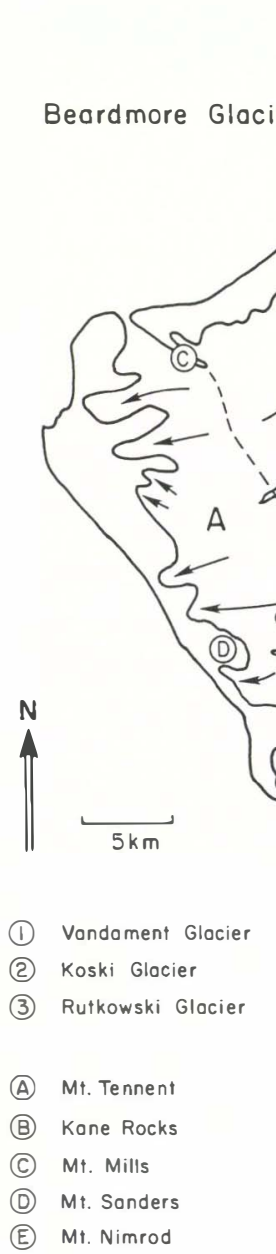

Mill Glocier
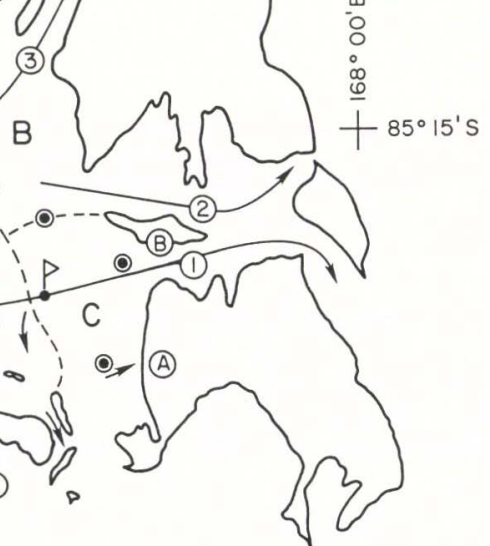

Fig. 2. Dominion Range location map.

\section{ICE-SURFACE AND ICE-THICKNESS MEASUREMENTS}

The early part of the field season was devoted to establishing an optimum site for recovery of an ice core (Fig. 2). Maps, visual observations of ice-surface topography, and the presence of bedrock ridges all validated initial estimates that the Dominion Range ice cover is either entirely separated from or only minimally connected to the East Antarctic ice sheet and hence the site is a catchment for local precipitation. Exposed bedrock ridges flanking the Dominion Range are cavernously weathered. Comparison of the degree of cavernous weathering with that examined in the general region of the Queen Maud Mountains by Mayewski and Goldthwait (1985) suggests that ice has not topped these ridges for at least several tens of thousands of years.

Based on an examination of USGS (I:250 000) topographic maps and a radio echo-sounding survey conducted in the field, the Dominion Range ice mass is divisible into three major drainage basins, referred to as $\mathbf{A}$, $B$, and C (Fig. 2). The radio-echo survey employed a mono-pulse system (after Watts and Isherwood, 1978) and was centered primarily over drainage basin C. It included measurements at 42 stations, ten of which were occupied at least twice to test instrument reproducibility, which proved to be less than the error inherent in reading the oscilloscope. Final ice-thickness measurements were determined using Watts and Isherwood's (1978) relationship with adjustments for density made using measurements from the core. Crevassed areas in the southern section of basin C, lower Vandament Glacier, prevented the recovery of useful radio echo-sounding data from this area.

Drainage basin C surface topography (Fig. 3) is characterized by a general surface slope to the east, thus

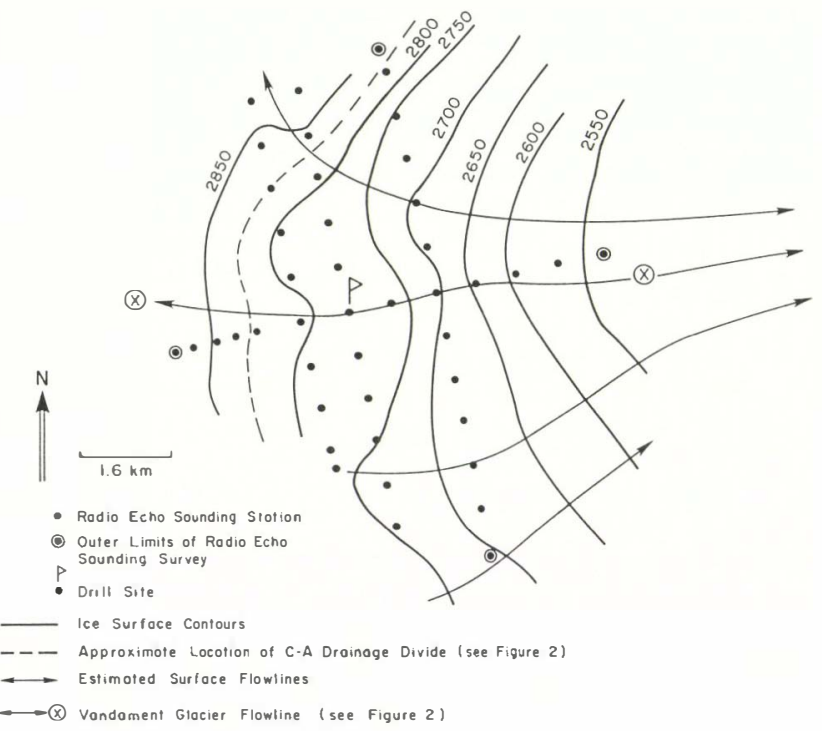

Fig. 3. Drainage basin $C$ ice surface.

the major part of the drainage for $C$ discharges through Vandament Glacier. Ice thicknesses in basin $\mathrm{C}$ (Fig. 4) range from $\cong 350$ to $<50 \mathrm{~m}$ with the thickest areas north of the drill site and in the Mount Tennant area. Thinner ice areas are found in the western part of the basin close to the $\mathrm{C}-\mathrm{A}$ surface ice divide, and the remainder of the basin is characterized by ice depths most commonly in the range $200-300 \mathrm{~m}$. The general gradient of the subglacial topography is east-south-east.

The core site (see Figs 2, 3, and 4) was chosen $\cong 1.7 \mathrm{~km}$ down-flow line from the $\mathrm{C}-\mathrm{A}$ ice divide to minimize complications due to flow right on the divide and $\cong 1.7 \mathrm{~km}$ up-slope from the base camp to minimize the effects of any local chemical contamination from the camp. Although it cannot be demonstrated definitively with the data available, it appears that if any East Antarctic ice penetrates drainage basin $C$ from the Mount Tennant area that this ice would be deflected eastward toward Vandament Glacier and hence away from the drill site. A comparison between ice-surface contours (Fig. 3) and ice-thickness contours 


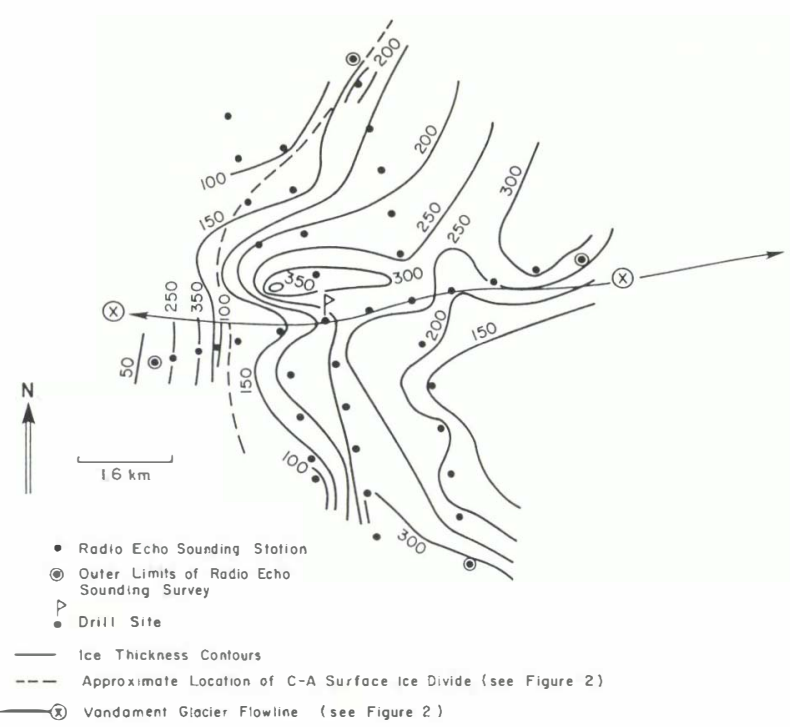

Fig. 4. Drainage hasin $C$ ice thichnesses.

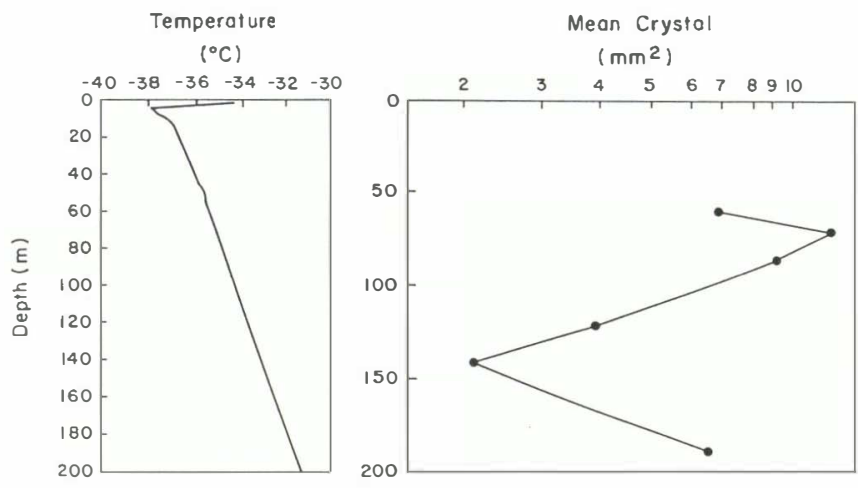

Fig. 5. Temperature, density (smoothed). and mean crystal size as a function of depih.
(Fig. 4) in the area of the Vandament Glacier flow line suggests that the ice in this area must be strained.

\section{BORE-HOLE TEMPERATURE AND MEAN ANNUAL NET ACCUMULATION}

Temperature measurements were made at $5 \mathrm{~m}$ intervals (Fig. 5) down the entire length of the bore hole using a thermistor system designed by L. Hansen (PICO). Twenty readings at $20 \mathrm{~s}$ intervals were made at each depth immediately following a $10 \mathrm{~min}$ equilibrium period. Instrument error is $\pm 0.02^{\circ} \mathrm{C}$ based on duplicate measurements. The mean annual temperature, at $10 \mathrm{~m}$ depth, is $-37.3^{\circ} \mathrm{C}$, and the temperature at the base of the core, 201 mbar ( $\mathrm{m}$ beneath surface), is $-31.3^{\circ} \mathrm{C}$. Radio echosounding results suggest that the glacier at this point is $<230 \mathrm{~m}$ thick, hence there is little doubt that the base of this ice mass is frozen to the bed.

Mean annual net accumulation was determined by a combination of measurements, including total $\beta$-activity, 210

volcanic horizons. Details concerning the dating of the core appear in Spencer and others (in press). We report here only the resultant mean annual net accumulation for the upper $\approx 100 \mathrm{~m}$ of the core which is $\approx 35 \mathrm{~kg} \mathrm{~m}^{-2} \mathrm{a}^{-1}$.

The mean annual temperature and mean annual accumulation at this site are consistent with relationships presented by Gow (1968) for a survey of Antarctic sites.

\section{CRYSTAL SIZE AND FABRIC}

Horizontal and vertical thin sections were cut from core samples taken at depths of 59.5, 70.7, 85.3, 122.7, 143.2, and 190 mbar. Mean crystal size (Fig. 5) within each section was determined from measurements of the long and short axes of individual crystals. Fabrics (Fig. 6) were determined from measurements of $c$-axis orientations using a Rigsby stage (Langway, 1958).

Mean crystal cross-section increased from $\approx 7 \mathrm{~mm}^{2}$ at $59.5 \mathrm{mbar}$ to $\approx 13 \mathrm{~mm}^{2}$ at $70.7 \mathrm{mbar}$ and then decreased progressively to $\approx 2 \mathrm{~mm}^{2}$ between 70.7 and $143.2 \mathrm{mbar}$ before increasing to $\approx 7 \mathrm{~mm}^{2}$ at $190 \mathrm{mbar}$. Sections at 59.5 and
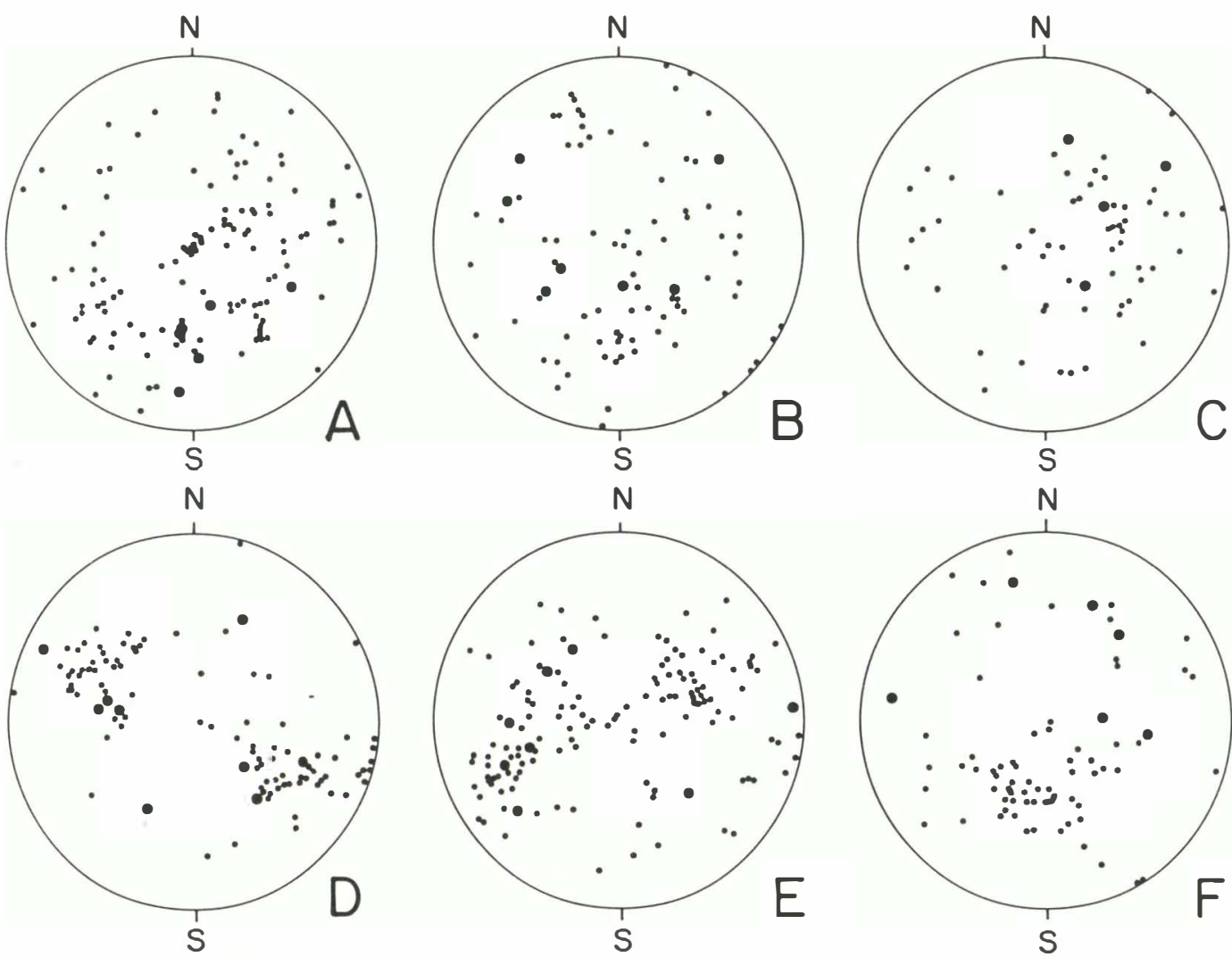

Fig. 6. Fahric point-scatter diagrams illustrating c-axis orientations at (A) 59.52 mhar. (B) 70.71 mhar. (C) 85.28 mbar, (D) 122.65 mbar, (E) 143.18 mbar, and (F) 190.00 mbar. Larger dots represent crystals that are greater than twice the average grain-size. 
70.7 mbar exhibited random fabrics. At 82.3 mbar, a weakly preferred orientation of $c$-axes is evident with local $c$-axis concentrations of $8 \%$ per $1 \%$ area of projection. By 122.7 mbar, $c$-axes group into two maxima located approximately $35^{\circ}$ from the vertical. c-axis concentrations as high as $10 \%$ per $1 \%$ were observed. At $143.2 \mathrm{mbar}$, a girdle pattern appears with local c-axis concentrations as high as $12 \%$ per $1 \%$ area. A ring or small girdle fabric is present at 190 mbar.

The marked decrease in size of crystals between 70.7 and 143.2 mbar may indicate the onset of shearing. Moderate development of $c$-axis fabrics from the same depth interval might support a shearing process; however, a lack of tight single-pole fabrics would indicate that shearing is not yet a dominant process. Crystal coarsening at 190 mbar could signal the onset of recrystallization in the basal layers of ice. However, such a process would tend to be impeded by the generally low temperatures at the site. It was not possible to obtain azimuthally oriented core and this, together with the limited observations of the texture and fabric of the ice, prevent us from developing a unique flow history for this part of the Dominion Range ice field. Notably, the quality of the ice core recovered deteriorated from whole to fractured core interspersed with whole sections from this depth downward. It was not possible in the field, however, to resolve whether the core quality was necessarily due to strained ice or problems with the cutters.

\section{OXYGEN ISOTOPES OF ICE}

A continuous $\delta^{18} \mathrm{O}_{\mathrm{ICE}}$ profile was obtained for the ice core using $25 \mathrm{~cm}$ increments for most of the core and $2-3 \mathrm{~cm}$ samples in the sections studied for ice chemistry. $\delta^{18} \mathrm{O}_{I F E}$ is defined here as being equal to $\left(\left({ }^{18} \mathrm{O} /{ }^{16} \mathrm{O}\right)_{\text {sample }}\right.$ $\left.\left({ }^{18} \mathrm{O} / \mathrm{fG}^{\mathrm{O}} \mathrm{O}\right)_{\text {SMow }}\right) /\left({ }^{18} \mathrm{O} /{ }^{16} \mathrm{O}\right)_{\text {sMow }}$ and SMOW is Standard Mean Ocean Water. $\delta^{18} \mathrm{O}_{\mathrm{ICE}}$ for $50 \mathrm{~cm}$ averages of the data appear in Figure 7.

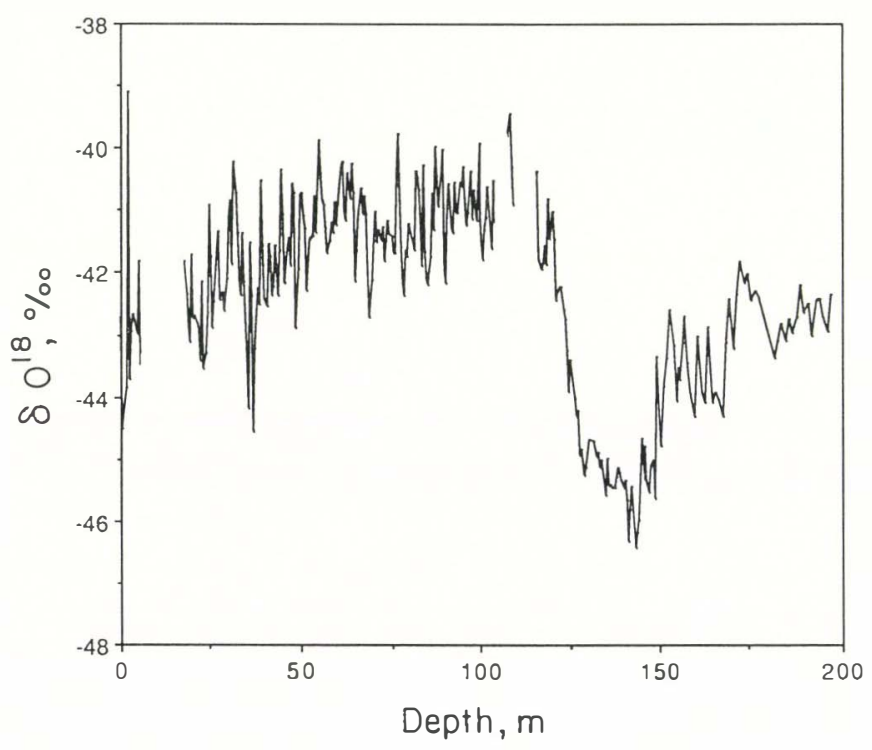

Fig. 7. $\delta^{18} O_{\text {ICE }}$ measurements down-core $(50 \mathrm{~cm}$ averages $)$.

For the upper $\approx 100 \mathrm{~m}$ of the core there appears to be a small trend toward less negative $\delta^{18} \mathrm{O}_{\mathrm{ICE}}$ values with depth. The sections below $\approx 100 \mathrm{~m}$ are significantly lighter and are marked by a drop of $\approx 5 \%$ from $\approx 100$ to $145 \mathrm{mbar}$ followed by a rise of $\approx 2-3 \%$. The $\approx 5.0 \%$ marked drop is similar to the glacial/interglacial $\delta$ changes of $5.4 \%$ and about 5\% observed at Dome C (Lorius and others, 1979) and at Vostok (Lorius and others, 1985), respectively.

\section{ICE CHEMISTRY}

While details of the distribution of major chemical species in the core are left to other papers (e.g. Spencer and others, in press), it is worth mentioning the marked difference in the distribution of $\mathrm{Cl}^{-}$and $\mathrm{SO}_{4}^{2-}$ in the upper half of the core ( 2 and $3 \mathrm{~cm}$ sampling interval) and one of the few intact sections that could be analyzed from the lower half of the core at 138.0-138.4 mbar $(2 \mathrm{~cm}$ sampling interval). Marine aerosols and volcanic activity represent the primary sources for both $\mathrm{Cl}^{-}$and $\mathrm{SO}_{4}^{2-}$ to the Antarctic ice sheet. While volcanic source inputs would be expected to be randomly distributed in the record, differences in marine source input would result in trends in the data series that probably reflect changes in air-mass circulation and/or ocean/ice relationships. Average values of $\mathrm{Cl}^{-}(\approx 250 \mathrm{ppb})$ and $\mathrm{SO}_{4}^{2-}(\approx 300 \mathrm{ppb})$ in the $138.0-138.4 \mathrm{~m}$ section are two to three times those in the upper half of the core. The contrast between lower-level ice, as represented by the 138.0 $-138.4 \mathrm{~m}$ section, and the upper $\approx 100 \mathrm{~m}$ of ice is striking. Although the higher $\mathrm{SO}_{4}^{2-}$ and $\mathrm{Cl}^{-}$concentrations in the deeper sections could coincidently be a volcanic layer, none of the volcanic events in the upper half of the core is as high in concentration or as broad in time span. We conclude, therefore, that the deeper section marks a period which differs from upper sections either in marine source intensity, in transport pathway, and/or for some unknown reason.

The upper and lower sections of the core also appear to differ in their concentration of methanesulfonic acid (MSA). MSA is a constituent of marine aerosols which is formed as a result of the atmospheric oxidation of DMS. Variations in MSA concentration in the core reflect changes in the flux of DMS from the oceans, in the patterns of aeolian transport, and/or in precipitation rate (Saigne and Legrand, 1987). A noticeable difference was, however, observed between the four samples measured from an upper section of the core $(29-30 \mathrm{mbar}$; MSA conc. $=2.2 \pm 0.2)$ and five samples measured from a lower core section $(138-139 \mathrm{mbar}$; MSA conc. $=5.7 \pm 1.0)$.

\section{ISOTOPIC COMPOSITION OF TRAPPED GASES}

The isotopic composition of trapped $\mathrm{O}_{2}$ and $\mathrm{N}_{2}$ in two sections of the Dominion Range core appear in Table I. The isotopic composition of the 83 mbar samples was similar to the isotopic composition of Recent ( $<1500$ a B.P.) samples of ice from five different cores taken from Antarctica and Greenland (paper in preparation by T. Sowers and others). The isotopic composition of the 139 mbar samples had $\delta^{18} \mathrm{O}_{\mathrm{ATM}}\left(\mathrm{O}_{2}\right)$ values which were enriched, compared to Recent ice samples, by $1.0 \pm 0.13 \%$.

During the transition from glacial to interglacial periods, isotopically light melt water from glaciers was introduced to the oceans, resulting in a decrease in the $\delta^{18} \mathrm{O}_{\text {water }}$ of sea-water (where $\delta^{18} \mathrm{O}_{\text {water }}=\left(\left(\mathrm{H}_{2}{ }^{18} \mathrm{O}\right)\right.$ $\left.\left.\left.\mathrm{H}_{2}{ }^{16} \mathrm{O}\right)_{\text {water }} /\left(\mathrm{H}_{2}{ }^{18} \mathrm{O} / \mathrm{H}_{2}{ }^{16} \mathrm{O}_{\text {SMOw }}\right)-1\right) 10^{3}\right)$. water Photosynthesizing organisms utilized the isotopically depleted melt water to form $\mathrm{O}_{2}$ which was mixed into the paleoatmospheric $\mathrm{O}_{2}$ reservoir causing the $\delta^{18} \mathrm{O}_{\mathrm{ATM}}\left(\mathrm{O}_{2}\right)$ of air to fall (where $\delta^{18} \mathrm{O}_{\mathrm{ATM}}\left(\mathrm{O}_{2}\right)=\left(\left({ }^{18} \mathrm{O}^{16} \mathrm{O}\right) /\left({ }^{16} \mathrm{O}_{2}\right){ }_{\text {paleo-air }} /\left(\left(\left({ }^{18} \mathrm{O}^{16} \mathrm{O}\right) /\left({ }^{16} \mathrm{O}_{2}\right)\right.\right.\right.$ presentday atmosphere $)-1)\left(0^{3}\right)$. Studies of the trapped gases in the Dome C core have shown that the isotopic composition of $\mathrm{O}_{2}$ trapped in the ice tracks the isotopic composition of sea-water over the past 20000 years (Bender and others, 1985). Since the $\delta^{18} \mathrm{O}_{\mathrm{ATM}}\left(\mathrm{O}_{2}\right)$ is constant throughout the atmosphere, one can use the composition of the $\mathrm{O}_{2}$ in the ice as a chronologic tool. We have used this tool to estimate the ages of two samples from the Dominion Range core.

Analysis of Recent samples of ice show that the trapped gases are enriched in both ${ }^{18} \mathrm{O}$ and ${ }^{15} \mathrm{~N}$ relative to the contemporaneous atmosphere (paper in preparation by $\mathrm{T}$. Sowers and others). The enrichment is probably the result of isotopic fractionation as the bubbles are sealed. Because atmospheric $\mathrm{N}_{2}$ has a very long residence time, the $\delta^{15} \mathrm{~N}$ of the atmospheric $\mathrm{N}_{2}$ is believed to have been constant for the last $10^{6}$ years (where $\delta^{15} \mathrm{~N}_{\mathrm{ATM}}\left(\mathrm{N}_{2}\right)=\left(\left({ }^{14} \mathrm{~N}\right.\right.$ $\left.\left.{ }^{15} \mathrm{~N} /{ }^{14} \mathrm{~N}_{2}\right)_{\text {paleo-air }} /\left(\left({ }^{14} \mathrm{~N}^{15} \mathrm{~N} /{ }^{14} \mathrm{~N}_{2}\right)_{\text {present-day }}{ }^{2}{ }^{1}\right) 10^{3}\right)$. Given this constancy, and the observed $\delta^{15} \mathrm{~N}-\delta^{18} \mathrm{O}$ relationship for gases trapped in modern ice, one can use the fractionation of the $\mathrm{N}_{2}$ trapped in ice to determine the $\delta^{18} \mathrm{O}_{\mathrm{ATM}}\left(\mathrm{O}_{2}\right)$ of past atmospheres using the following equation:

$\delta^{18} \mathrm{O}_{\mathrm{ATM}\left(\mathrm{O}_{2}\right)}=\delta^{18} \mathrm{O}_{\mathrm{ICE}\left(\mathrm{O}_{2}\right)}-\left(1.95\left(\delta^{15} \mathrm{~N}_{\mathrm{ICE}\left(\mathrm{N}_{2}\right)}\right)+0.08 \%\right)$ 
83 mbar sample

$(n=2)$ Average
std. dev.

139 mbar sample $(n=7)$

$$
\left.\delta^{15} N_{\mathrm{ICE}\left(N_{2}\right)^{*}} \quad \delta^{18} O_{\mathrm{ICE}\left(O_{2}\right)}\right)^{*} \quad \delta^{18} O_{\mathrm{ATM}}\left(O_{2}\right)^{\dagger}
$$

$0.17 \%$

$\pm 0.01 \%$

$0.37 \%$

$\pm 0.02 \%$

$-0.07 \%$

$\pm 0.01 \%$

$1.35 \%$

$\pm 0.02 \%$

\section{$1.00 \%$}

$\pm 0.13 \%$

* Reported data have been corrrected for the isotopic dependence on the elemental composition (paper in preparation by A.B. Kiddon and others). The data are reported relative to present-day-air, $\delta^{15} \mathrm{~N}$.

+ Isotopic composition of the contemporaneous atmosphere from which the trapped gases were derived, also reported relative to present-day air.

Knowing the $\delta^{18} \mathrm{O}$ unknown trapped gas sample by comparing the measured $\delta^{18} \mathrm{O}_{\mathrm{ATM}}\left(\mathrm{O}_{2}\right)$ value with the down-core record of $\delta^{18} \mathrm{O}_{\mathrm{ATM}}\left(\mathrm{O}_{2}\right)$ measured in the Dome $\mathrm{C}$ core (Bender and others, 1985). Using this $\delta^{18} \mathrm{O}_{\mathrm{ICE}}\left(\mathrm{O}_{2}\right)$ curve, we assign an ice age for the 139 mbar sample of $>10 \mathrm{ka}$ B.P. This age is expressed as a lower limit for two reasons. First, ice is older than the age of the trapped air (Schwander and Stauffer, 1984). Secondly, the $\delta^{18} \mathrm{O}_{\mathrm{ICE}}\left(\mathrm{O}_{2}\right.$ ) values for the Dome $\mathrm{C}$ record were not converted to $\delta^{18} \mathrm{O}_{\mathrm{ATM}\left(\mathrm{O}_{2}\right)}$ due to lack of $\delta^{15} \mathrm{~N}_{\mathrm{ICE}\left(\mathrm{N}_{2}\right)}$ measurements. Converting the Dome $\mathrm{C}$ $\delta^{18} \mathrm{O}_{\mathrm{ICE}\left(\mathrm{O}_{2}\right)}$ to $\delta^{18} \mathrm{O}_{\mathrm{ATM}}\left(\mathrm{O}_{2}\right)$ values will shift the inferred $\delta^{18} \mathrm{O}_{\mathrm{ATM}}\left(\mathrm{O}_{2}\right)$ record closer to the present-day air. By converting the Dome $\mathrm{C} \delta^{18} \mathrm{O}_{\mathrm{ICE}\left(\mathrm{O}_{2}\right)}$, one would increase the age of the Dominion Range 139 mbar samples.

\section{SUMMARY AND CONCLUSIONS}

The Dominion Range ice-core site is characterized by a mean annual temperature of $-37.3^{\circ} \mathrm{C}$ and a core-base temperature of $-31.3^{\circ} \mathrm{C}$ which is probably close to the basal ice temperature. The mean annual net accumulation is $\approx 35 \mathrm{~kg} \mathrm{~m}^{-2} \mathrm{a}^{-1}$

Dominion Range ice is divisible into three main drainage systems and a site close to the ice divide between two of these drainage systems was chosen for the recovery of a $201 \mathrm{~m}$ core. Differences between ice-surface and subglacial gradients in the area of the drill site suggest that some amount of lateral strain is imposed on the ice column. The difference in $\delta^{18} \mathrm{O}$ noted from $\approx 100$ to $\approx 145$ mbar in the Dominion Range core is similar to the glacial/interglacial $\delta$ changes observed at Dome $\mathrm{C}$ and Vostok. Measurement of $\delta^{18} \mathrm{O}_{\mathrm{ICE}\left(\mathrm{O}_{2}\right)}$ and $\delta^{15} \mathrm{~N}_{\mathrm{ICE}\left(\mathrm{N}_{2}\right)}$ of trapped gases indicates that ice at 139 mbar has an age $>10$ ka B.P.

If, as inferred from the measurements of $\delta^{18} \mathrm{O}_{\text {ICE }}$, $\delta^{18} \mathrm{O}_{\mathrm{ICE}\left(\mathrm{O}_{2}\right)}$, and $\delta^{15} \mathrm{~N}_{\mathrm{ICE}\left(\mathrm{N}_{2}\right)}$, the upper approximately half of the core column is Holocene in age and the ice below is glacial, then differences in both crystal size and chemical concentration discussed in this text may be more uniquely defined. While decreases in crystal size in the lower ice may' be due partly to shear, they may also simply reflect the cooler temperature of formation present during the glacial period as observed at Dome C (Duval and Lorius, 1980). Furthermore, increases in $\mathrm{Cl}^{-}$and $\mathrm{SO}_{4}^{2-}$ concentrations may be consistent with increases from Holocene to glacial age as measured from the Byrd core (Ragone and Finelli, 1972; Cragin and others, 1977) and Vostok core (Angelis and others, 1984), and the trend in MSA concentration is similar to that observed from Holocene to glacial ice measured at Dome C by Saigne and Legrand (1987).

The Dominion Range ice core provides relatively easy access to the Holocene record in a site that is potentially climatically sensitive. Were the quality of the lower half of the core better, it could also provide a view through the interglacial/glacial transition and into the last glacial period.
Future papers will document details of the Holocene signal in this region.

\section{ACKNOWLEDGEMENTS}

We should like to thank J.V. James (Glacier Research Group), H. Rufli (Switzerland), and B. Koci (Polar Ice Coring Office) for their help and friendship in the field. PICO ably recovered the $201 \mathrm{~m}$ core. L. Hansen (PICO) designed and provided the thermistor system used in this study. Thanks are also due to VXE-6. J. Dibb (Glacier Research Group) conducted the ${ }^{210} \mathrm{~Pb}$ and total B-activity measurements and $\mathrm{A}$. Wilson (University of Arizona) the ${ }^{14} \mathrm{C}$ analysis which were intrumental in the dating of the upper sections of this core. We are greatly indebted to them for their input. L. Preble patiently typed this paper. This research was supported by U.S. National Science Foundation grants DPP-84-00574, DPP-84-11108, and DPP-85-13699.

\section{REFERENCES}

Angelis, M. de, M. Legrand, J.R. Petit, N.I. Barkov, Ye.S. Korotkevitch, and V.M. Kotlyakov. 1984. Soluble and insoluble impurities along the $950 \mathrm{~m}$ deep Vostok core (Antarctica) - climatic implications. J. Atmos. Chem., 1, 215-239.

Bender, M., L.D. Labeyrie, D. Raynaud, and C. Lorius. 1985. Isotopic composition of atmospheric $\mathrm{O}_{2}$ in ice linked with deglaciation and global primary productivity. Nature, 318(6044), 349-352.

Cragin, J.H., M.M. Herron, C.C. Langway, $j r$, and G. Klouda. 1977. Interhemispheric comparison of changes in the composition of atmospheric precipitation during the Late Cenozoic era. In Dunbar, M.J., ed. Polar Oceans. Proceedings of the Polar Oceans Conference ... Montreal. May. 1974. Calgary, Arctic Institute of North America, $617-631$.

Denton, G.H., R.L. Armstrong, and M. Stuiver. 1971. The Late Cenozoic glacial history of Antarctica. In Turekian, K.K., ed. The Late Cenozoic glacial ages. New Haven, CT, and London, Yale University Press, 267-306.

Drewry, D.J. 1980. Pleistocene bimodal response of Antarctic ice. Nature, 287(5779), 214-216.

Duval, P. and C. Lorius. 1980. Crystal size and climatic record down to the last ice age from Antarctic ice. Earth Planet. Sci. Lell., 48(1), 59-64.

Gow, A.J. 1968. Deep core studies of the accumulation and densification of snow at Byrd Station and Little America V, Antarctica. CRREL Res. Rep. 197.

Langway, C.C., $j r$. 1958. Ice fabrics and the universal stage. SIPRE Tech. Rep. 62.

Lorius, C., L. Merlivat, J. Jouzel, and M. Pourchet. 1979. A 30,000-yr isotope climatic record from Antarctic ice. Nature, 280(5724), 644-648. 
Lorius, C., and 6 others. 1985. A 150,000-year climate record from Antarctic ice. Nature, 316(6029), 591-596.

Mayewski, P.A. and R.P. Goldthwait. 1985. Glacial events in the Transantarctic Mountains: a record of the East Antarctic ice sheet. In Turner, M.D. and J.F. Splettstoesser, eds. Geology of the Transantarctic Mountains. Washington, DC, American Geophysical Union, 275-324. (Antarctic Research Series 36.)

Ragone, S.E. and R.V. Finelli. 1972. Cationic analysis of the Byrd Station, Antarctica, ice core. CRREL Spec. Rep. 180 .

Saigne, C. and M. Legrand. 1987. Measurements of methanesulphonic acid in Antarctic ice. Nature, 330(6145), 240-242.
Schwander, J. and B. Stauffer. 1984. Age difference between polar ice and the air trapped in its bubbles. Nature, $311(5981), 45-47$.

Spencer, M.J., P.A. Mayewski, W.B. Lyons, M.S. Twickler, and P. Grootes. In press. A 3500 year ice chemistry record from the Dominion $\mathrm{R}$ ange, Antarctica: linkages between climatic variations and precipitation chemistry.

Stuiver, M., G.H. Denton, T.J. Hughes, and J.L. Fastook. 1981. History of the marine ice sheet in West Antarctica during the last glaciation: a working hypothesis. In Denton, G.H. and T.J. Hughes, eds. The last great ice sheets. New York, etc., J. Wiley and Sons, 319-436.

Watts, R.D. and W. Isherwood. 1978. Gravity surveys in glacier-covered regions. Geophysics, 43(4), 819-822.

MS. received 24 March 1988 and in revised form 10 May 1989 